\title{
Detrimental effect of deltamethrin on the central nervous system (synganglion) of Rhipicephalus sanguineus ticks
}

\author{
Melissa Carolina Pereira ${ }^{1}$ Ana Elisa Gasparotto ${ }^{1} \cdot$ \\ Juliana Paneczko Jurgilas ${ }^{1}$ - Letícia Aurora Coelho da Silva ${ }^{1}$ • \\ Mayara Cristina Pereira ${ }^{1}$ - Samantha Santos Silveira ${ }^{1}$ • \\ Thays Neigri Silva ${ }^{1}$ André Arnosti ${ }^{1} \cdot$ Maria Izabel Camargo-Mathias ${ }^{1}$
}

Received: 9 November 2016/Accepted: 25 January 2017/Published online: 9 February 2017

(C) Springer International Publishing Switzerland 2017

\begin{abstract}
Ticks are ectoparasites of medical and veterinary importance, which transmit many infectious agents, causing significant damage to the hosts. The "dog tick" Rhipicephalus sanguineus is responsible for transmitting several pathogens to dogs, motivating researchers to investigate efficient and sustainable control methods. Currently, chemical acaricides currently in use target the central nervous system (synganglion), which is responsible for controlling all the systemic functions of the ticks. Here, the neurotoxic potential of deltamethrin on the synganglion of unfed $R$. sanguineus female ticks was investigated. The results showed that the synganglion of the females belonging to the control group presented intact morphological characteristics; however, the ones from the treatment group (exposed to 1.5, 3.12 and $6.25 \mathrm{ppm}$ of deltamethrin) displayed alterations, which were increasingly intense as the concentration increased. Observed alterations were mainly in the cortex region and in the neuropile, indicating that the deltamethrin is neurotoxic.
\end{abstract}

Keywords Ticks · Acaricide $\cdot$ Neurotoxicity $\cdot$ Morphology

\section{Introduction}

Ticks, along with mites, constitute the subclass Acari, and as well as the other organisms belonging to the subphylum Chelicerata, they have a segmented body organized in two regions: the cephalothorax (also called the prosoma) and the abdomen (also called ophistosoma), both result of a "fusing" of the head and thorax regions (Ruppert et al. 2004). Externally, these ectoparasites are covered by a sclerotized and hardened cuticle

Maria Izabel Camargo-Mathias

micm@rc.unesp.br

1 Sao Paulo State University (UNESP) "Júlio de Mesquita Filho", Avenida 24 A, 1515, Rio Claro, SP 13506-900, Brazil 
mainly constituted by protein and polysaccharides (Ruppert et al. 2004). Within the Acari, the suborder Ixodida (=Metastigmata) is divided into three families: Ixodidae ("hard ticks"), Argasidae ("soft ticks") and Nuttalliellidae, a total of approximately 870 species (Ruppert et al. 2004). The former two are cosmopolitan, while the latter is exclusive from the afrotropical region (Pereira et al. 2008).

Ticks are important ectoparasites, once they transmit infectious agents and cause significant damage to the hosts due to their hematophagous behavior (Pereira et al. 2008). Among the arthropods, ticks are the vectors of the widest variety of pathogenic microorganisms affecting the human being and other animal hosts as well (Jongejan and Uilenberg 2004; Sonenshine and Roe 2014). Diseases transmitted by ticks have deserved attention worldwide (Jongejan and Uilenberg 2004), once more than 16 diseases affecting the human being and 19 harming cattle and other animals (including companion pets) have been reported (Sonenshine and Roe 2014).

The Rhipicephalus sanguineus sensu lato (s. 1), also known as "dog tick", is a cosmopolitan species believed to have originated in Africa. The global distribution of these ectoparasites is associated with their preference to parasitize domestic dogs (primary host), and this species was easily disseminated in hot and temperate areas (Flechtmann 1973). The main pathogens transmitted to dogs by this species are Babesia canis (Nambiuvu), Rickettsia canis and Hepatozoon canis, responsible for causing anemia (Flechtmann 1973).

In 2010, Dantas-Torres reported cases of human parasitism by $R$. sanguineus s. 1., consolidating the importance of this species. According to the World Health Organization (2004) these ectoparasites are responsible for the transmission of Rickettsia conorii (Mediterranean spotted fever) in Europe; and, according to Demma et al. (2005), of R.rickettsii (Rocky Mountain spotted fever) in Arizona, EUA.

Ixodidae females attach to a host and there remain, feeding in a single (Flechtmann 1973). The eggs produced after mating, fecundation and engorgement are laid in the soil after the females drop from the host (Flechtmann 1973).

The methods to control these ectoparasites are varied, including the use of fungi (Frazzon et al. 2000); vaccines and natural predators, such as the egret Egretta ibis (Hitchner et al. 1975 apud Freitas et al. 2005). However, the most efficient resource is the utilization of chemical acaricides mainly the synthetic ones (Freitas et al. 2005; Borges et al. 2007; Oliveira et al. 2009, 2015; Roma et al. 2014).

Due to the great current concern with sustainability, natural resources with acaricide properties have been investigated, mainly plants. Castor oil esters, the azadirachtin obtained from neem plant and andiroba oil have been proven effective to control these ectoparasites (Fernandes et al. 2001; Farias et al. 2007; Arnosti et al. 2011a, b; Denardi et al. 2011).

Despite the recognized efficiency of the chemical acaricides, they usually presents several drawbacks: the high application cost, the contaminations of the environment (soil and rivers) and food (meat and milk) by the residues (Nolan 1985; Pruett 1999 apud Freitas et al. 2005), and the emergence of resistant tick populations (Crampton et al. 1999 apud Freitas et al. 2005). However, pyrethroid-based chemicals acaricides have been proven efficient in controlling arthropods, and among them is the deltamethrin (Elliott et al. 1978). Oliveira et al. (2008, 2009) and Roma et al. (2009, 2010) demonstrated that commercial chemical acaricides, even in low dosages, affect the morphophysiology of male and female tick germ cells (Pereira et al. 2009, 2011) and also the salivary glands, responsible for secreting the saliva, important mixture for the feeding process of these ectoparasites (Nodari et al. 2011, 2012a, b). 
The literature has reported that the acaricides, mainly the synthetic ones, act on the morphophysiology of the central nervous system (synganglion) (Roma et al. 2014). In this sense, several authors as Sonenshine and Roe (2014) and Roma et al. (2012a, b, 2014) have been studying the central nervous system of ticks, called synganglion, and described it as a mass of fused nerves with multiple extensions. Located between the gnathosoma and the genital pore, close to the first pair of legs (Roma et al. 2012b), the synganglion is externally covered by the neurilemma and the perineurium; and internally subdivided into a cortex, which contains the neuron cell body, and a neuropile, medullar region with the neuron extensions (Roma et al. 2012b).

Considering this information and: (a) the public health importance of the ticks (Pereira et al. 2008), (b) the difficulty to control them, and (c) the economic losses caused by these ectoparasites (Horn 1983 apud Pereira et al. 2008), the present study aimed to demonstrate how the chemical compound deltamethrin (active ingredient of Butox ${ }^{\circledR}$ P CE25, manufactured by Intervet do Brasil Veterinária, Cruzeiro, SP) at the concentrations of 1.5, 3.12, and $6.25 \mathrm{ppm}$ (approximately 23, 11 and 5 times lower than the one recommended by the manufacturer, respectively) modifies the morphology of the synganglion (central nervous system) from unfed $R$. sanguineus s. 1. females, once this organ is responsible for controlling the systemic functions of the ticks.

\section{Materials and methods}

\section{Rhipicephalus sanguineus s.l. ticks}

For the bioassay, 20 unfed Rhipicephalus sanguineus s.l. females were used and divided into four groups; i.e., control and the groups treated with deltamethrin concentrations, all of them lower than the one recommended by the manufacturer (approximately $35 \mathrm{ppm}$ ). The specimens were supplied by the Brazilian Central of Studies on Ticks Morphology (BCSTM), UNESP, campus Rio Claro, SP, Brazil, and maintained under controlled conditions $\left(28 \pm 1{ }^{\circ} \mathrm{C}, 80 \%\right.$ humidity, photoperiod $\left.12 \mathrm{~h}\right)$ in BOD incubator.

\section{Preparing the deltamethrin formulations and immersion test of the unfed Rhipicephalus. sanguineus s.l. females}

The deltamethrin was obtained from the compound Butox ${ }^{\circledR}$ P CE25 (manufactured by Intervet do Brasil Veterinária), at the commercialized concentration of $25 \mathrm{~g} / \mathrm{L}$ $(25.000 \mathrm{ppm})$. According to the manufacturer, to obtain the application dosage (approximately $35 \mathrm{ppm}$ ) it is necessary to dilute $10 \mathrm{~mL}$ of the compound in $7 \mathrm{~L}$ of water. Thus, for the concentrations proposed in the present study $(6.25,3.12$ and $1.5 \mathrm{ppm})$, crescent dilutions in distilled water were performed.

Four groups with five unfed females each were established as follows: Group I (Control) ticks exposed to distilled water; Group II-exposed to deltamethrin $1.5 \mathrm{ppm}$ (23 times lower than the manufacturer's recommendation); Group III-exposed to deltamethrin $3.12 \mathrm{ppm}$ (11 times lower than the manufacturer's recommendation) and Group IVexposed to deltamethrin $6.25 \mathrm{ppm}$ (5 times lower than the manufacturer's recommendation). The exposure was performed immersing each specimen for $5 \mathrm{~min}$ in each solution. The same procedure was adopted for the control group, where the ticks were immersed in 
distilled water. After the immersion, the ticks were sieved and washed in running tap water to remove the excess of chemical product and dried with absorbent paper.

The groups were transferred to labeled Petri dishes and covered with permeable plastic film. The samples were kept in BOD incubator Eletrolab El 202 (Biological Oxygen Demand) at $27 \pm 1{ }^{\circ} \mathrm{C}$ and UR $80 \pm 10 \%$ for 5 days to allow the acaricide action. The control group individuals were kept in a different chamber to avoid possible interference of the deltamethrin (extremely volatile product).

\section{Harris' hematoxylin and aqueous eosin technique (Junqueira and Junqueira 1983)}

For the histological analysis, the ticks were dissected in saline solution $0.06 \%$ for the removal of the dorsal shield and then fixed in paraformaldehyde $4 \%$ for 7 days. After, the samples were immersed in phosphate buffer solution (PBS) for $24 \mathrm{~h}$, dehydrated in graded ethanol series at 70, 80, 90 and 95\% (30 min each bath), embedded in historesin Leica ${ }^{\circledR}$ for 7 days and included in plastic molds containing resin + polymerizer. The blocks were sectioned using microtome LEICA RM 2255, and the $3 \mu$ m-thick sections were mounted on glass slides and stained with Harris' hematoxylin for $10 \mathrm{~min}$. After washed in running tap water for $5 \mathrm{~min}$, the sections were stained with aqueous eosin for $5 \mathrm{~min}$, and washed again in running tap water. Posteriorly, the slides were allowed to air dry and were rapidly immersed in xylol, covered with Canada balsam and a coverslip. The permanent slides were analyzed and photo documented using bright field light microscope LEICA DM750.

\section{Results}

\section{Group I (control)}

The histological results regarding the control group, i.e., the synganglion of the $R$. sanguineus s. 1. females not exposed to deltamethrin (active ingredient of Butox ${ }^{\circledR}$ P CE 25), corroborate Roma et al. (2012b) (Fig. 1 A1-3), and the characteristics of the organ are summarized as follows: (a) the outer layer covering the organ is acellular and called neurilemma (b) the inner layer is composed of glial cells and is called perineurium. The organ is still constituted by (c) a cortical region, which contains the neuron cell bodies and (d) the neuropile, region with fibrous aspect where the neuron extensions are found. The subperineurium, also formed by glial cells, is found between these two regions (cortex and neuropile).

\section{Group II (treated with $1.5 \mathrm{ppm}$ of deltamethrin)}

The individuals exposed to the concentration of $1.5 \mathrm{ppm}$ of deltamethrin, showed slight alterations (Fig. 1 B1-3), noting that the neurilemma and the perineurium were not morphologically modified. The cortex showed evidence of morphological disorganization onset, with the emergence of vacuoles in the interior of the cells and pyknotic nuclei among the intact ones found in this region (Fig. 1 B2).

The subperineurium remained intact, while the neuropile showed little vacuolation of the extracellular matrix among the neuron fibers (Fig. 1 B3). 

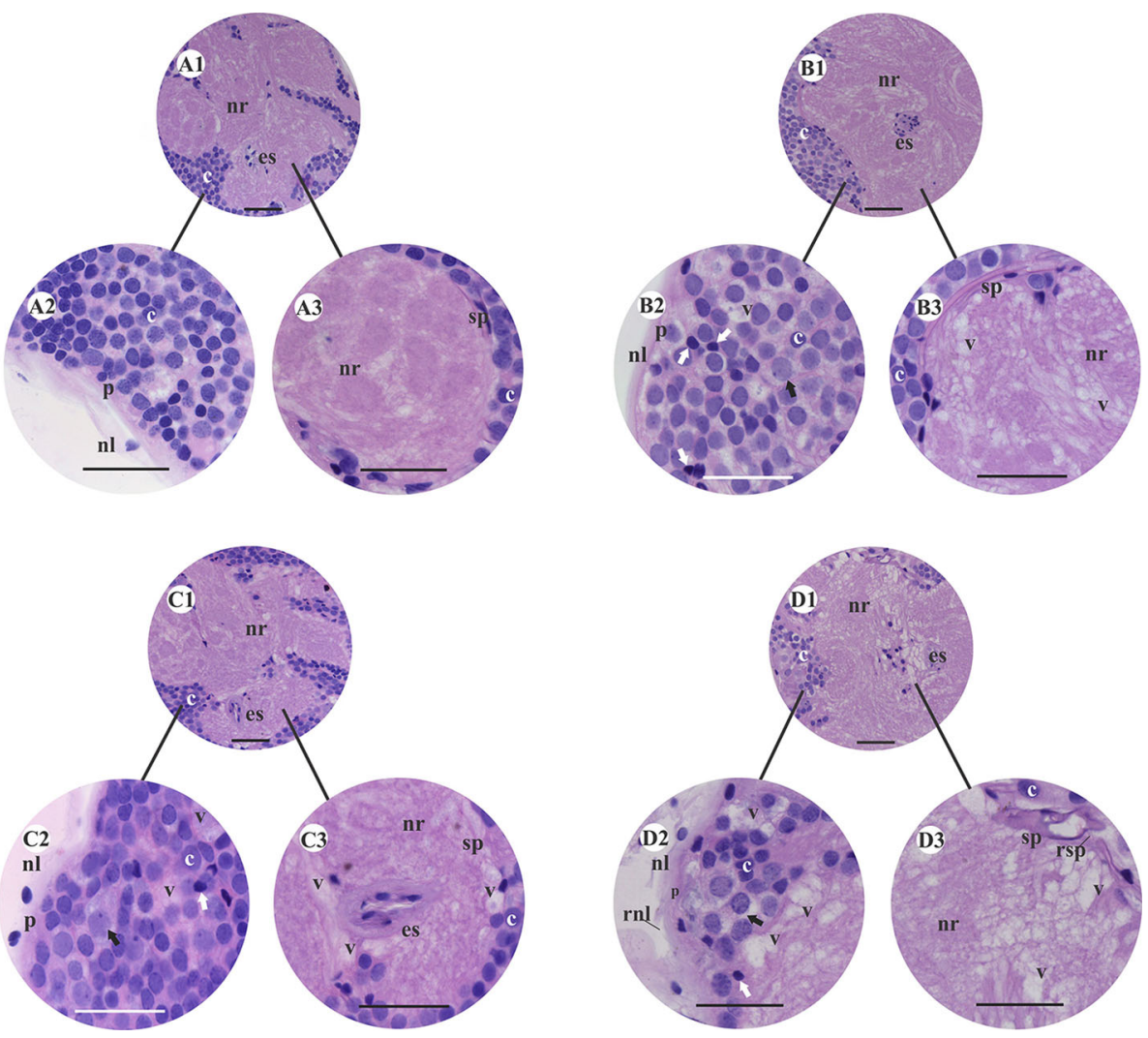

Fig. 1 Histological sections of the synganglion of unfed Rhipicephalus sanguineus $\mathrm{s}$. 1. females exposed to the acaricide deltamethrin, control (A1-A3) and treatment groups (B1-D3), stained with hematoxylin-eosin (HE). A1-A3 Histological sections of the synganglion from the control group. A1 General viewand, A2 detail of the neurilemma $(n l)$, perineurium $(p)$ and neuron cell bodies in the cortex $(c)$, and $\mathbf{A 3}$ subperineurium $(s p)$ and neuron fibers in the neuropile $(n r)$, without morphological alterations. B1-B3 Histological sections of the synganglion of the individuals from group I (1.5 ppm of deltamethrin). B1 General viewand, B2 detail of pyknotic nuclei (white arrows) cells with nuclear hypertrophy (black arrows) in the cortical region and $\mathbf{B 3}$ onset of neuron fiber disorganization in the neuropile. C1-C3 Synganglion of the females from group II (3.12 ppm of deltamethrin). C1 General viewand, C2 detail of the cortex with pyknotic and hypertrophic nuclei, as well as vacuoles $(v)$ originated from the degenerative process. C3 Structural disorganization of the neuropile region with the onset of vacuolation in the extracellular matrix among the neuron fibers, mainly next to the esophageal opening (es). D1-D3 Histological sections of the synganglion from group III (6.5 ppm of deltamethrin). D1 General view and intense vacuolation in the extracellular matrix, mainly next to the esophageal opening and D2 detail of the cortex with several vacuoles in the cytoplasm of neuron cell bodies, cells with many pyknotic and hypertrophic nuclei and rupture of the neurilemma $(r n l)$; $\mathbf{D 3}$ rupture of the subperineurium in the neuropile region $(r s p)$ and detail of the structural disorganization of the neuron fibers. Bars A1, B1, C1, D1: $50 \mu \mathrm{m}$; A2-A3, B2-B3, C2-C3, D2-D3: $20 \mu \mathrm{m}$

\section{Group III (treated with 3.12 ppm of deltamethrin)}

In the individuals belonging to group III (Fig. 1 C1-3), exposed to the concentration of $3.12 \mathrm{ppm}$ of deltamethrin, the synganglion external membranes were intact (Fig. $1 \mathrm{C} 2$ ). However, other significant alterations were observed in this group when compared with the previous and the control one, mainly in the cortical region and the neuropile. 
The cortex showed a higher level of morphological disorganization of the neuron cell bodies and more intense vacuolation in the cytoplasm in comparison with the previous treatment group (Fig. $1 \mathrm{C} 2$ ). In addition, hypertrophic and pyknotic nuclei were found, suggesting a degenerative process onset (Fig. 1 C2).

The subperineurium did not display morphological alterations; however, a higher level of vacuolation in the extracellular matrix was observed among the neuron fibers from this layer in comparison with the first treatment and control groups (Fig. 1 C3).

\section{Group IV (treated with $6.25 \mathrm{ppm}$ of deltamethrin)}

The synganglion of the females exposed to the concentration of $6.25 \mathrm{ppm}$ showed intense morphological alterations (Fig. 1 D1-3). The membranes of the neurilemma and perineurium started to present irregularities, such as folds and pleats, and rupture of the neurilemma was also observed (Fig. 1 D2). The cortex displayed a high level of disorganization and cell degeneration, including modification in the nuclear DNA compaction. Several nuclei showed: a) irregular morphology, b) pyknotic aspect and c) hypertrophy (frequent in case of cell death) (Fig. 1 D2). This region presented neuron cell bodies with intensely vacuolated cytoplasm, with several spaces among them, suggesting that some cells have degenerated, leaving empty spaces, not stained by the histological technique applied (Fig. 1 D2).

The subperineurium, located between the cortex and the neuropile, was also modified, presenting irregularities, such as folds and ruptures throughout its extension (Fig. 1 D3).

The neuropile presented intense structural disorganization of the neuron fibers, characterized by the presence of several empty spaces in the extracellular matrix (Fig. 1 D3), mainly in the region next to the esophageal opening crossing part of the synganglion (Fig. 1 D1) and dividing it in two portions: infra and supraesophageal.

For better understanding, the results are summarized in Table 1.

\section{Discussion}

In the search for new alternatives to control ticks, several acaricides have been studied through the analysis of the main organs of these ectoparasites exposed to different synthetic chemical compounds, such as thepermethrin and fipronil, tested on the nervous (Roma et al. 2013) and reproductive systems (Oliveira et al. 2008, 2009; Roma et al. 2009,2010 ), and on the salivary glands, critical organs for the feeding and fixation processes (Pereira et al. 2009, 2011; Nodari et al. 2011, 2012a, b). Thus, the present study analyzed the effects of deltamethrin (active ingredient of Butox ${ }^{\circledR}$ P CE25) at three different concentrations $(1.5,3.12$ and $6.5 \mathrm{ppm})$ on the synganglion of unfed Rhipicephalus sanguineus s. 1. females, since this organ controls important functions in these ectoparasites.

The morphohistological results revealed that the synganglion of the individuals from the control group (group I) was intact, corroborating Roma et al. (2012b). In the individuals from the treatment groups (II, III and IV), exposed to different concentrations of deltamethrin, the synganglion showed gradual alterations in their morphology, mainly in the cortex and neuropile regions. These alterations were proportional to the increase in the concentrations applied.

The individuals from group II (exposed to $1.5 \mathrm{ppm}$ of deltamethrin) presented the cortical region cells with slight disorganization in addition to some vacuoles. These 
Table 1 Summary of the main alterations found in each region of the synganglion of unfed Rhipicephalus sanguineus s. 1. females exposed to deltamethrin (active ingredient of Butox ${ }^{\circledR}$ P CE25) concentrations of 1.5, 3.12 and $6.5 \mathrm{ppm}$

\begin{tabular}{|c|c|c|c|c|c|}
\hline $\begin{array}{l}\text { Deltamethrin } \\
(\mathrm{ppm})\end{array}$ & Neurilemma & Perineurium & Cortex & Subperineurium & Neuropile \\
\hline 1.5 & Intact & Intact & $\begin{array}{l}\text { Few vacuoles in the } \\
\text { cytoplasm of } \\
\text { neuron cell } \\
\text { bodies; presence } \\
\text { of cells with } \\
\text { pyknotic nuclei }\end{array}$ & Intact & $\begin{array}{l}\text { Neuron fiber } \\
\text { disorganization } \\
\text { onset }\end{array}$ \\
\hline 3.12 & Intact & Intact & $\begin{array}{l}\text { Onset of structural } \\
\text { disorganization in } \\
\text { the cortex and } \\
\text { vacuolation in the } \\
\text { cytoplasm of } \\
\text { neuron cell } \\
\text { bodies; pyknotic } \\
\text { and hypertrophic } \\
\text { nuclei }\end{array}$ & Intact & $\begin{array}{l}\text { Neuron fiber } \\
\text { disorganization; } \\
\text { vacuolation in the } \\
\text { extracellular } \\
\text { matrix among the } \\
\text { fibers }\end{array}$ \\
\hline 6.5 & $\begin{array}{l}\text { Presence of } \\
\text { folds, } \\
\text { pleats and } \\
\text { rupture }\end{array}$ & $\begin{array}{l}\text { Presence of } \\
\text { folds and } \\
\text { pleats }\end{array}$ & $\begin{array}{l}\text { Significant } \\
\text { structural } \\
\text { disorganization of } \\
\text { the cortex; } \\
\text { lintense } \\
\text { vacuolation } \\
\text { process in the } \\
\text { neuron cell } \\
\text { cytoplasm; } \\
\text { neurons with } \\
\text { irregular } \\
\text { morphology, } \\
\text { pyknosis and } \\
\text { nuclear } \\
\text { hypertrophy }\end{array}$ & $\begin{array}{l}\text { Presence of } \\
\text { folds and } \\
\text { rupture }\end{array}$ & $\begin{array}{l}\text { Significant } \\
\text { structural } \\
\text { disorganization of } \\
\text { the neuropile and } \\
\text { in the } \\
\text { arrangement of } \\
\text { the neuron fibers; } \\
\text { intense } \\
\text { vacuolation } \\
\text { process in the } \\
\text { extracellular } \\
\text { matrix among the } \\
\text { fibers, mainly } \\
\text { next to the } \\
\text { esophageal } \\
\text { opening }\end{array}$ \\
\hline
\end{tabular}

intracytoplasmic vacuoles could be the first evidence that the cells would be developing defense mechanisms against the toxic agent, in an attempt to eliminate damaged regions, organelles, or even whole cells from the cytoplasm, allowing a turnover of the still useful components (Roma et al. 2013).

Still in the cortical region, some cells with pyknotic nuclei were found among the ones with regular nuclei, suggesting that, even with the defense strategies, the cells could not revert the damages caused by the product in the tissue, starting a degenerative process (Furquim et al. 2008a, b; Roma et al. 2012b, 2013).

The neuropile of the individuals belonging to group II consisted in a fibrous region, organized in lobules, containing axons and dendrites (nerve cells extensions) (Sonenshine and Roe 2014). At the lowest deltamethrin concentration (1.5 ppm), this region displayed small spaces in the extracellular matrix among the neuron fibers, a probable response to the damages occurred in the cortex cells. 
In the females exposed to $3.12 \mathrm{ppm}$ of deltamethrin (group III), the cortex of the synganglion showed neuron cell bodies with a more vacuolated cytoplasm, with intense tissue disorganization, suggesting more extensive damages caused by the degeneration process. In addition, the presence of hypertrophic and pyknotic nuclei clearly indicate that the deltamethrin would be causing cell death in the nerve tissue. These results corroborate Furquim et al. (2008a, b), who described atypical cell death mechanisms (apoptosis and autophagy occurring simultaneously) in $R$. sanguineus s. 1 , and Nodari et al. $(2011,2012 a, b)$ who observed cell death processes induced by toxic agents (permethrin) in the salivary glands of the same species.

The neuropile of the individuals from group III (exposed to $3.12 \mathrm{ppm}$ of deltamethrin), showed slight structural disorganization in the extracellular matrix among the neuron fibers, suggesting that, even in low concentrations, the chemical would be altering the central nervous system functioning, affecting thetransmission of nerve impulses from the axons and dendrites to the other organs, corroborating studies by Roma et al. (2013) on the effects of permethrin.

Significant morphological alterations were observed in the highest concentration of deltamethrin (group IV-6.25 ppm), confirming the highly toxic profile of the chemical. According to Marzouk et al. (2001), Roma et al. (2012b, 2013) and Sonenshine and Roe (2014) the synganglion is covered by two peripheral membranes: the neurilemma and the perineurium, both playing important roles: act as a selective barrier for the entrance of substances in the organ and support the metabolic regulation of the neuron activities through glial cells, respectively. Thus, the damages found in the synganglion external membranes of the individuals from group IV (folds, pleats and rupture parts of the neurilemma) suggest loss of integrity and functionality resulting from the exposure to the toxic agent.

The synganglion cortical region in the females from group IV exposed to deltamethrin (6.5 ppm) was heavily altered, displaying a high level of tissue disorganization and degeneration, mainlyin the cytoplasm of neuron cell bodies, with significant vacuolation. In addition, several cells with hypertrophic nuclei and evidence of cell death (nuclear pyknosis) were observed, corroborating Nodari et al. (2011, 2012a, b), Oliveira et al. (2008, 2009), Pereira et al. (2011) and Roma et al. (2009, 2013), who confirmed the occurrence of cell death in different tissues of $R$. sanguineus s.l. ticks induced by the exposure to acaricides.

The cortical region of the tick synganglion contains neurosecretory centers where important substances to be released into the hemolymph are synthetized for the regulation of the organ (Sonenshine and Roe 2014). These centers can be damaged when the nerve tissue is exposed to a toxic agent (Prullage et al. 1992). Therefore, damages to the cortex, as the ones described in this study, affect the release of substances associated with regulation mechanisms and impair the whole functioning of the central nervous system.

The subperineurium, layer located between the cortex and the neuropile (Roma et al. 2012b; Sonenshine and Roe 2014), was only affected in the females from group IV, which showed irregular folds throughout the extension and rupture in some points. This kind of damage allowed the neuron cell bodies to dislocate from the cortex towards the neuropile, causing a complete structural disorganization of the organ and consequent loss of functionality. These data corroborate Roma et al. (2013), who reported the degenerative process of the synganglion in female ticks exposed to permethrin.

Still regarding the individuals from group IV, the neuron fibers in the neuropile showed intense structural disarrangement, with the presence of several empty spaces in the extracellular matrix among them, mainly next to the esophageal opening. This organ 
divides the neuropile in two parts, infra and supraesophageal (Roma et al. 2012b; Sonenshine and Roe 2014) and the alterations found next to its opening in the synganglion suggest that the chemical compound would be entering nervous system via esophageal opening (probably due to the oral ingestion of the product during immersion), and not only via peripheral membranes (neurilemma and perineurium) damaged by the chemical.

The significant structural disorganization of the nerve tissue after exposed to the highest concentration of the chemical $(6.5 \mathrm{ppm})$ revealed a gradual degeneration process; i.e., the higher the concentration, the greater the damage. These results corroborate Roma et al. (2013), who analyzed the synganglion of $R$. sanguineus s. l. females exposed to permethrin. However, Nodari et al. (2011, 2012a, b), studying the salivary glands of $R$. sanguineus s. 1. also exposed to permethrin, observed that the most significant damages were caused by intermediate concentrations, not the higher ones, suggesting that different tissues would react differently when exposed to acaricides; therefore, the cell and tissue responses would be specific for each toxic agent. Nonetheless, it is important to emphasize that depending on the chemical agent, the possibility of response overlap cannot be discarded.

As the synganglion is regarded as a key organ in the metabolic process of the ticks, its morphophysiological alteration triggers a complete disorganization of the functions in the animals exposed to a toxic product. Among these functions are the successful reproduction, via ovary development, and feeding, critical process for the survival of the ectoparasite.

Therefore, it can be assumed that the deltamethrin (active ingredient of Butox ${ }^{\circledR}$ P CE25) was potentially neurotoxic, even when applied at low concentrations (1.5, 3.12 and $6.5 \mathrm{ppm}$ ), causing cell death in the nerve tissue by apoptosis. In addition, the chemical damaged other systems of the organism considering that, after morphophysiologically disorganized, the synganglion was prevented from controlling other critical processes, such as reproduction and feeding.

Acknowledgments The authors are grateful to the Fundação de Amparo à Pesquisa do Estado de São Paulo-FAPESP (Grant: 2015/20745-6) and to the Conselho Nacional de Desenvolvimento Científico e Tecnológico-CNPq (Grant: 300625/2012-0), M.I. Camargo-Mathias academic carrier research fellowship for the financial support. The authors would like to thank Mr. Gerson de Mello Sousa for technical support.

\section{Compliance with ethical standards}

Conflict of interest The authors declare that there are no conflicts of interest.

\section{References}

Arnosti A, Brienza PD, Chierice GO et al (2011a) Effects of Ricinus communis oil esters on salivary glands of Rhipicephalus sanguineus (Latreille 1806 Acari: Ixodidae). Exp Parasitol 127:569-574

Arnosti A, Brienza PD, Furquim KCS et al (2011b) Effects of ricinoleic acid esters from castor oil of Ricinus communis on the vitellogenesis of Rhipicephalus sanguineus (Latreille, 1806) (Acari:Ixodidae) ticks. Exp Parasitol 127:575-580

Borges LMF, Soares SF, Fonseca IN et al (2007) Resistência carrapaticida em larvas de Rhipicephalus sanguineus (Acari: Ixodidae) de Goiânia-GO, Brasil. Rev Patol Trop 36:87-95

Crampton AL, Baxter GD, Barker SC (1999) Identification and characterization of a cytochrome P450 gene and processed pseudogene from an arachnid: the cattle tick, Boophilus microplus. Insect Biochem Mol Biol 29:377-384

Dantas-Torres F (2010) Biology and ecology of the brown dog tick, Rhipicephalus sanguineus. Parasit Vectors 3:1-11

Demma LJ, Traeger MS, Nicholson WL et al (2005) Rocky Mountain spotted fever from an unexpected tick vector in Arizona. N Engl J Med 353:587-594 
Denardi SE, Bechara GH, Oliveira PR, Camargo-Mathias MI (2011) Inhibitory action of neem aqueous extract (Azadirachta indica A. Juss) on the vitellogenesis of Rhipicephalus sanguineus (Latreille, 1806) (Acari: Ixodidae) ticks. Microsc Res Tech 74:889-899

Elliott M, Janes NF, Potter C (1978) The future of pyrethroids in insect control. Annu Rev Entomol 23:443-469

Farias MPO, Sousa DP, Arruda AC et al (2007) Eficácia in vitro do óleo da Carapa guianensis Aubl. (andiroba) no controle de Boophilus microplus (Acari: Ixodidae). Rev Bras Plantas Med 9:68-71

Fernandes FF, Freitas EP, Silva JR et al (2001) Toxic effects and in vitro inefficacy of deltamethrin on larvae of Rhipicephalus sanguineus from Goiania, Goias, Brazil. Rev Soc Bras Med Trop 34:159-165

Flechtmann CHW (1973) Ácaros de importância médico-veterinária. Livraria Nobel SA, São Paulo

Frazzon APG, Junior IDSV, Masuda A et al (2000) In vitro assessment of Metarhizium anisopliae isolates to control the cattle tick Boophilus microplus. Vet Parasitol 94:117-125

Freitas DRJ, Pohl PC, Vaz-Junior IS (2005) Caracterização da resistência para acaricidas no carrapato Boophilus microplus. Acta Sci Vet 33:109-117

Furquim KCS, Bechara GH, Camargo-Mathias MI (2008a) Death by apoptosis in salivary glands of females of the tick Rhipicephalus sanguineus (Latreille, 1806) (Acari:Ixodidae). Exp Parasitol 119:152-163. doi:10.1016/j.exppara.2008.01.021

Furquim KCS, Bechara GH, Camargo-Mathias MI (2008b) Degeneration of salivary glands of males of the tick Rhipicephalus sanguineus (Latreille, 1806) (Acari, Ixodidae). Vet Parasitol 154:325-335. doi:10. 1016/j.vetpar.2008.03.013

Hitchner SB, Domermuth CH, Purchase HG, Williams JE (1975) Isolation and identification of avian pathogens. Arnold Printing Corporation, New York

Horn SC (1983) Prováveis prejuízos causados pelos carrapatos (Boletim de Defesa Sanitária). Ministério da Agricultura, Brasília

Jongejan F, Uilenberg G (2004) The global importance of ticks. Parasitology 129:S3-S14. doi:10.1017/ S0031182004005967

Junqueira LCU, Junqueira LMMS (1983) Técnicas básicas de citologia e histologia. Livraria Editora Santos, São Paulo

Marzouk AS, Mohamed FSA, Omar NR (2001) Fine structure of the synganglion of unfed female Rhipicephalus (Rhipicephalus) sanguineus (Latreille) (Ixodoidea: Ixodidae). J Egypt Soc Parasitol 31:1-12

Nodari EF, Roma GC, Furquim KCS et al (2011) Cytotoxic effects of permethrin in salivary glands of Rhipicephalus sanguineus (Latreille, 1806) (Acari: Ixodidae) semi-engorged females. Exp Parasitol 128:151-158

Nodari EF, Roma GC, Furquim KCS et al (2012a) Action of permethrin on Rhipicephalus sanguineus (Latreille, 1806) (Acari: Ixodidae) semi-engorged females: Morpho-physiological evaluation of salivary glands. Ticks Tick Borne Dis 3:219-226

Nodari EF, Roma GC, Furquim KCS, Camargo-Mathias MI (2012b) Degenerative process and cell death in salivary glands of Rhipicephalus sanguineus (Latreille, 1806) (Acari: Ixodidae) semi-engorged female exposed to the acaricide permethrin. Microsc Res Tech 75:1012-1018. doi:10.1002/jemt.22025

Nolan J (1985) Mechanisms of resistance to chemicals in arthropod parasites of veterinary importance. Vet Parasitol 18:155-166

Oliveira PR, Bechara GH, Camargo-Mathias MI (2008) Evaluation of cytotoxic effects of fipronil on ovaries of semi-engorged Rhipicephalus sanguineus (Latreille, 1806) (Acari: Ixodidae) tick female. Food Chem Toxicol 46:2459-2465

Oliveira PR, Bechara GH, Marin-Morales MA, Camargo-Mathias MI (2009) Action of the chemical agent fipronil on the reproductive process of semi-engorged females of the tick Rhipicephalus sanguineus (Latreille, 1806) (Acari: Ixodidae). Ultrastructural evaluation of ovary cells. Food Chem Toxicol 47:1255-1264

Oliveira PR, Remédio RN, Bechara GH et al (2015) Dinotefuran-induced morphophysiological changes in the ovaries and midgut of semi-engorged females Rhipicephalus sanguineus Latreille, 1806 (Acari: Ixodidae) ticks. Parasitol Res 115:829-849. doi:10.1007/s00436-015-4814-3

Pereira MC, Labruna MB, Szabó MPJ, Klafke GM (2008) Rhipicephalus (Boophilus) microplus: biologia, controle e resistência. MedVet, São Paulo

Pereira CPM, Oliveira PR, Bechara GH, Camargo-Mathias MI (2009) Effects of fipronil (active ingredient of Frontline ${ }^{\circledR}$ ) on salivary gland cells of Rhipicephalus sanguineus (Latreille, 1806) (Acari: Ixodidae) females. Vet Parasitol 166:124-130

Pereira CPM, Oliveira PR, Furquim KCS et al (2011) Fipronil-induced cell death in salivary glands of Rhipicephalus sanguineus (Latreille, 1806) (Acari: Ixodidae) semi-engorged females. Exp Parasitol 127:481-489. doi:10.1016/j.exppara.2010.10.003

Pruett JH (1999) Immunological control of arthropod ectoparasites: a review. Int J Parasitol 29:25-32 
Prullage JB, Pound JM, Meola SM (1992) Synganglial morphology and neurosecretory centers of adult Amblyomma americanum (L.) (Acari: Ixodidae). J Med Entomol 29:1023-1034

Roma GC, Oliveira PR, Pizano MA, Camargo-Mathias MI (2009) Determination of LC 50 of permethrin acaricide in semi-engorged females of the tick Rhipicephalus sanguineus (Latreille, 1806) (Acari: Ixodidae). Exp Parasitol 123:269-272

Roma GC, Furquim KCS, Bechara GH, Camargo-Mathias MI (2010) Permethrin-induced morphological changes in oocytes of Rhipicephalus sanguineus (Acari: Ixodidae) semi-engorged females. Food Chem Toxicol 48:825-830

Roma GC, Nunes PH, Oliveira PR et al (2012a) Central nervous system of Rhipicephalus sanguineus ticks (Acari: Ixodidae): an ultrastructural study. Parasitol Res 111:1277-1285

Roma GC, Nunes PH, Remédio RN, Camargo-Mathias MI (2012b) Synganglion histology in different stages of Rhipicephalus sanguineus ticks (Acari: Ixodidae). Parasitol Res 110:2455-2463. doi:10.1007/ s00436-011-2785-6

Roma GC, Camargo-Mathias MI, Oliveira PR et al (2013) Neurotoxic action of permethrin in Rhipicephalus sanguineus (Latreille, 1806) (Acari: Ixodidae) female ticks. Morphological and cytochemical evaluation of the central nervous system. Vet Parasitol 196:482-491. doi:10.1016/j.vetpar.2013.02.025

Roma GC, Camargo-Mathias MI, Nunes PH, Bechara GH (2014) Ultrastructure of the synganglion in the larvae and nymphs of tick Rhipicephalus sanguineus (Latreille, 1806)(Acari: Ixodidae). Int J Acarol 40:207-213

Ruppert EE, Fox RS, Barnes RD (2004) Invertebrate zoology: a functional evolutionary approach, 7th edn. Thomson-Brooks/Cole, Belmont

Sonenshine DE, Roe RM (2014) Biology of ticks, vol 1. Oxford University Press, New York

World Health Organization (2004) The vector-borne human infections of Europe: their distribution and burden on public health. WHO Regional Office for Europe, Copenhagen 